\title{
Molecular breast imaging and background uptake of fibroglandular tissue as tools to predict neoplasms in dense breasts
}

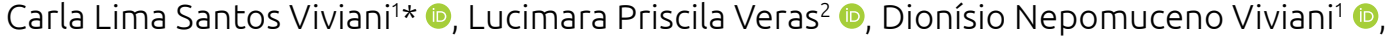 \\ Amanda Sofia Silva Mascarenhas ${ }^{\circledR}$, Rivadávio Fernandes Batista de Amorim³ ${ }^{\circ}$
}

\section{ABSTRACT}

The sensitivity of mammography as a screening method is low in dense breasts, which are associated with a high risk of developing tumors. Thus, molecular breast imaging (MBI) with background uptake (BPU) of fibroglandular tissue can be used as a complementary method. The aim of this review was to synthesize the existing evidence on these important diagnostic imaging tools. Three electronic databases were searched to identify original articles, including publications dating from September 2010 and September 2020, in English, conducted in any location, and addressing at least one aspect related to dense breasts and Breast-specific gamma-imaging (BSGI). In total, 22 studies were reviewed. Several advantages of MBI and BPU as complementary methods of screening for dense breasts were found. Among them, we can mention the increase in breast cancer detection rate, easy implementation in clinical practice, high patient satisfaction, low cost and good reproducibility. In view of the good results found in our review, we can conclude that the implementation of MBI, especially with BPU, can be a promising complementary tool for screening of dense breasts.

KEYWORDS: molecular imaging; breast neoplasms; radionuclide imaging; breast density.

\section{INTRODUCTION}

Breast cancer is the type of cancer with the highest incidence among women around the world, with 2,088,849 new cases reported worldwide in 2018, which corresponds to $11.6 \%$ of all cases of cancer detected in that year ${ }^{1}$.

Mammography is the standard screening method to detect breast cancer due to its high sensitivity in most cases, enabling diagnoses at the earliest stages and, therefore, reducing mortality rates. However, this method has some relevant limitations. One of them is the use in dense breasts, since the sensitivity of the mammogram decreases as the breast density increases.

Dense breasts are strongly associated with the risk of developing tumors. However, as this is a highly prevalent condition, it is impractical for physicians to consider that all women with this type of breast constitution are at high risk, as this would justify additional tests or preventive options in almost half of the female population. To identify the subset of women with dense breasts who are most at risk for breast cancer and who is most likely to benefit from these strategies, improved risk stratification tools are needed ${ }^{2}$.

Molecular Breast Imaging (MBI), also known as Breast-specific gamma-imaging(BSGI), which is a nuclear medicine scan performed with the Sestamibi-99mTc radiotracer and a dedicated gamma camera, can be one of these tools. New technologies, including cadmium-zinc-telluride (CZT) detectors, silicon photodiodes, and small detectors placed in the configuration of a mammograph, allow to reduce so drastically the radiation dose to obtain images in this type of study that it has become acceptable as a screening exam.

In the assessment of dense breasts by magnetic resonance imaging (MRI), the level of gadolinium contrast enhancement within the fibroglandular tissue, termed Background Parenchymal Enhancement (BPE), has been associated with both prevalent and incident breast cancer. Similarly, the background uptake (BPU) of fibroglandular tissue in MBI depicts the level of Sestamibi${ }^{99 \mathrm{~m}} \mathrm{Tc}$ uptake in that tissue, and is also strongly associated with the risk of breast cancer ${ }^{3}$.

${ }^{1}$ Brasília Medical Images, SHLS Nuclear Medicine - Brasília (DF), Brazil.

${ }^{2}$ School of Health Sciences - Brasília (DF), Brazil.

${ }^{3}$ Department of Pathology, Medical School, Universidade de Brasília - Brasília (DF), Brazil.

*Corresponding author: carlalimasantos@hotmail.com

Conflict of interests: nothing to declare.

Received on: 02/03/2021. Accepted on: 09/06/2021 
Given the current importance of BPU as a tool for screening cancer in dense breasts and the lack of studies on the subject, we decided to carry out an integrative literature review aiming to better guide the scientific community on the subject.

\section{METHOD}

The decision to carry out an integrative review was aimed at a potential view of studies carried out with different designs.

\section{Data sources and research strategy:}

To find articles in the literature, a search was carried out in the following databases: Web of Science, PubMed and Medical Literature Analysis and Retrieval System Online (Medline). The following strategy was used in both researched bases: (("molecular breast imaging" OR "MBI” OR "breast specific gamma imaging” OR "breast-specific gamma imaging" OR "BSGI") AND ("dense breast” OR "background parenchymal uptake” OR “BPU”)).

\section{Inclusion, exclusion and eligibility criteria}

All studies included in this review met the following inclusion criteria:

- papers written in English and published between September 2010 and September 2020;

- $\quad$ studies conducted in any location;

- papers exploring at least one aspect related to dense breasts and scintigraphy performed in specific mammary gamma-camera.

Since the number of publications found on the topic was not large, quantitative, qualitative and mixed studies were included in the review. The exclusion criteria were:

- journal publications with impact factor less than 2;

- review or case report formats.

The following eligibility criteria were defined:

- papers that were specifically relevant to the topic addressed;

- publications that did not primarily address technical tools.

\section{Selection and screening of articles}

First, the title and abstract of the papers were evaluated by two authors as to the adequacy to the theme, using the inclusion and exclusion criteria. Then, articles selected for evaluation of the full text were independently reviewed by two authors, and then jointly in case of any discrepancies. A third author was consulted to resolve divergences and to assist in the final decision on whether to include or exclude the article.

\section{Quality assessment}

The critical evaluation of selected articles was made by two independent reviewers on the methodological quality. For quality assessment, two distinct checklists were used: the Critical
Appraisal Skills Program (CASP) checklist for qualitative studies $^{4}$, and the Joanna Briggs Institute (JBI) checklist for quantitative studies ${ }^{5}$. A third reviewer was consulted to reconcile any discrepancies in quality assessments.

\section{Data extraction and synthesis}

Data extraction tables were created independently by two authors, and then modified as necessary (Tables 1 and 2). Information on these tables included author, year of publication, country, study characteristics, and main results. Data were extracted by one author and verified by two other authors for accuracy. A meta-analysis of quantitative studies was not feasible due to the heterogeneity of the studies' approaches to measure and report knowledge.

\section{RESULTS}

\section{Summary of study selection}

The search in databases identified 117 records. Of these, 24 were duplicates and were later removed. The initial screening process based on title and abstract resulted in the exclusion of 55 articles, leaving 38 for full-text reading. Then, another 16 articles were excluded, 14 for not focusing specifically on the topic and 2 for being technical tools. The search and selection process is shown in Figure 1.

\section{Studies' characteristics}

The 22 studies included in this review were published between 2011 and 2020 and conducted in 3 countries: the United States of America $(n=18)$, China $(n=2)$ and South Korea $(n=2)$. Table 1 shows their outstanding characteristics.

\section{Quality of studies included}

Study quality was rated as good (score $\geq 80$ ), regular (score 50-79\%), and poor (score $<50 \%$ ). Due to the limited literature available in this area, all studies were included in this review, regardless of their quality. However, none of them had a bad qualification.

\section{Studies' results}

The breast cancer detection rate is increased when MBI is associated with mammography ${ }^{6,7}$, especially in cases of dense breasts ${ }^{6}$. In the study by Rhodes et al., when associating MBI with mammography, there was the detection of 8.8 cases of breast cancer per 1,000 women with dense breasts on mammography ${ }^{6}$.

Other studies have shown that MBI was useful to predict whether breast lesions are malignant or benign, and found a high overall sensitivity in this type of study when it comes to detecting breast cancer (95.4\%), with no significant difference considering non-dense and dense breasts, regardless of breast density assessed by mammography ${ }^{8,9}$. 
Table 1. Characteristics of the studies.

\begin{tabular}{|c|c|c|c|}
\hline $\begin{array}{l}\text { Author and year of } \\
\text { publication }\end{array}$ & Location & Methodology & Sample \\
\hline Hruska et al., $2018^{2}$ & MayoClinic, USA & $\begin{array}{l}\text { Case-control study } \\
\text { Survey questionnaires Review of medical data }\end{array}$ & 239 individuals \\
\hline Hruska et al., $2021^{3}$ & MayoClinic, USA & $\begin{array}{c}\text { Retrospective cohort study Analyses of MBI } \\
\text { studies with BPU assessment and medical data } \\
\text { review }\end{array}$ & 2,992 women \\
\hline Rhodes et al., $2015^{6}$ & MayoClinic, USA & $\begin{array}{c}\text { Prospective study } \\
\text { MBI Image Analysis }\end{array}$ & 1,585 women \\
\hline Brem et al., 2016 & $\begin{array}{l}\text { The George Washington University } \\
\text { Medical Faculty, USA }\end{array}$ & $\begin{array}{c}\text { Retrospective study } \\
\mathrm{MBI} \text { and mammography image analysis }\end{array}$ & 849 women \\
\hline Choi et al., $2018^{8}$ & $\begin{array}{c}\text { Incheon St. Mary's Hospital, College } \\
\text { of Medicine, South Korea }\end{array}$ & $\begin{array}{c}\text { Retrospective study } \\
\text { MBl image analysis } \\
\text { Breast Biopsy Results }\end{array}$ & 231 women \\
\hline Rechtman et al., $2014^{9}$ & $\begin{array}{c}\text { The George Washington University, } \\
\text { USA }\end{array}$ & $\begin{array}{l}\text { Retrospective evaluation } \\
\text { MBI image analysis } \\
\text { Breast Biopsy Results }\end{array}$ & $\begin{array}{l}341 \text { women }(347 \\
\text { breast assessed) }\end{array}$ \\
\hline Conners et al., $2012^{10}$ & MayoClinic, USA & $\begin{array}{l}\text { Observational study } \\
\text { Observing MBI results }\end{array}$ & $50 \mathrm{MBI}$ exams \\
\hline Rhodes et al., $2020^{11}$ & MayoClinic, USA 2019 & Qualitative study & NR \\
\hline Shermis et al., $2016^{12}$ & ProMedicaBreastCare Center, USA & $\begin{array}{c}\text { Retrospective study } \\
\text { MBI, mammography and MRI image analysis } \\
\text { Breast Biopsy Results }\end{array}$ & 1,696 patients \\
\hline Shermis et al., $2017^{13}$ & ProMedica Breast Care Center, USA & Qualitative study & NR \\
\hline Zhang et al., $2020^{14}$ & $\begin{array}{l}\text { Hospital of Zhejiang University } \\
\text { School of Medicine, China }\end{array}$ & $\begin{array}{c}\text { Retrospective study } \\
\text { Analysis of ultrasound, mammography and BSGI } \\
\text { images }\end{array}$ & 364 women \\
\hline Yu et al., $2016^{15}$ & $\begin{array}{l}\text { Zhejiang University School of } \\
\text { Medicine, Hangzhou, China }\end{array}$ & $\begin{array}{c}\text { Retrospective study } \\
\text { Analysis of MBI, mammography, ultrasound and } \\
\text { MRI images }\end{array}$ & 357 women \\
\hline Rhodes et al., $2011^{16}$ & MayoClinic, USA & $\begin{array}{c}\text { Prospective study } \\
\mathrm{MBI} \text { and mammography image analysis } \\
\text { Breast Biopsy Results }\end{array}$ & 936 women \\
\hline Hendrick et al., $2016^{17}$ & Universidade do Colorado, USA & $\begin{array}{l}\text { Retrospective study } \\
\text { Use of data from Rhodes et al., } 2015 \\
\text { Analysis of mammography, MBI and } \\
\text { mammography associated with MBI. }\end{array}$ & 1,595 women \\
\hline Hruska et al., $2015^{18}$ & MayoClinic, USA & $\begin{array}{l}\text { Prospective single-institution study } \\
\text { Review of mammography and MBI studies } \\
\text { Determining the costs of breast exams }\end{array}$ & 1,585 women \\
\hline Hruska et al., $2016^{19}$ & MayoClinic, USA & $\begin{array}{l}\text { Retrospective case-control study } \\
\text { Review of medical data and MBI images }\end{array}$ & 241 women \\
\hline Hruska et al., $2019^{20}$ & MayoClinic, USA & $\begin{array}{c}\text { Prospective study, pilot } \\
\text { Review of medical data, application of } \\
\text { questionnaires and analysis of MBI studies }\end{array}$ & 21 women \\
\hline Yoon et al., $2015^{21}$ & $\begin{array}{c}\text { EwaWomansUniversity Seul, South } \\
\text { Korea }\end{array}$ & $\begin{array}{c}\text { Retrospective study } \\
\text { MBI, MRI and mammography image analysis } \\
\text { Medical data collection }\end{array}$ & 145 women \\
\hline Ching et al., $2018^{22}$ & $\begin{array}{c}\text { The George Washington University, } \\
\text { USA }\end{array}$ & $\begin{array}{l}\text { Retrospective study } \\
\text { MBI image analysis } \\
\text { Breast biopsy results }\end{array}$ & 153 women \\
\hline Hruska et al., $2015^{23}$ & MayoClinic, USA & $\begin{array}{c}\text { Retrospective study } \\
\text { Review of medical data, questionnaires } \\
\text { MBI and mammography analysis }\end{array}$ & 1,149 women \\
\hline Hruska et al., $2015^{24}$ & MayoClinic, USA & $\begin{array}{c}\text { Cohort study } \\
\text { Collection of medical data, measurement of } \\
\text { hormone levels and analysis of MBI studies }\end{array}$ & 42 women \\
\hline Dibble $2021^{25}$ & $\begin{array}{l}\text { Alpert Medical School of Brown } \\
\text { University, USA }\end{array}$ & Editorial comment & NR \\
\hline
\end{tabular}

NR: not reported; MBI: molecular breast imaging; MRI: magnetic resonance. 
Table 2. Findings of the studies.

\section{Author, year of \\ publication, study design}

Hruska et al., $2018^{2}$

Case-control study

\section{Objectives}

Interventions/ methods

To develop and evaluate a new quantitative method that assesses BPU, to compare quantification to qualitative categorization, and to determine the association of BPU with the risk of developing breast cancer.

To examine the association of BPU with breast cancer and estimate the absolute risk and

Hruska et al., $2021^{3}$ Retrospective cohort study

discriminatory accuracy of BPU by means of a cohort study.

To evaluate the diagnostic performance of $\mathrm{MBI}$ in the Rhodes et al., $2015^{6}$ Prospective study evaluation of women with dense breasts after alterations that reduced the radiation dose.
The association of quantitative BPU with breast cancer was examined.

Categorization of

patients according

to $\mathrm{BPU}$ in $\mathrm{MBI}$ exams
Decrease in radiation dose in MBI study.
Results/Conclusions
BPU quantification is a reproducible method that can predict the risk of breast cancer, as well as a qualitative method,

regardless of the density seen on mammography and hormonal factors.

\section{Brem et al., $2016^{7}$}

Retrospective study

Choi et al., $2018^{8}$
Retrospective study

To determine the increase in breast cancer detection when using MBI in conjunction with mammography to assess women at high risk for breast cancer.

To investigate which feature of BSGI uptake in women who were recently diagnosed with breast cancer was associated with malignancy.
$\mathrm{BPU}$ in $\mathrm{MBI}$ is an independent risk factor for breast cancer, with a strongest association among postmenopausal women with dense breasts.

Rechtman et al., $2014^{9}$
Retrospective study

\begin{tabular}{l} 
Retrospective study \\
\hline Conners et al., 2012 \\
Observational study
\end{tabular}

Observational study

The addition of low-dose radiation MBI

to routine mammographic evaluation pointed to a $67 \%$ increase in sensitivity to detect neoplasms.

$\mathrm{MBI}$ increased breast cancer detection by $1.7 \%$ in the study, suggesting that it is beneficial for the detection breast cancer in high-risk women, particularly those with dense breasts.

Analysis of radiotracer uptake characteristics in BSGl is useful to predict whether breast lesions are malignant or benign.

To evaluate the sensitivity of $\mathrm{MBI}$ for detecting breast cancer in dense and non-dense breasts.
To determine the diagnostic agreement and accuracy in the use of a lexical pattern of description in the interpretation of the MBI.
NA

NA

NA

To investigate whether the MBI exam has a route to supplemental screening for dense breasts.
BSGI has high sensitivity for detecting breast cancer in women with dense and non-dense breasts and is an effective complementary imaging method for the assessment of breasts.

Newly trained radiologists assessing MBI with the proposed lexical pattern achieved a high rate of agreement and diagnostic accuracy.
Rhodes et al., 202011

Qualitative study
To retrospectively assess the clinical performance of molecular breast imaging as a complementary Shermis et al., 2016 Retrospective study screening tool for women with dense breast tissue.
To describe how MBI is used

in conjunction with recent technological advances in other imaging methods for breast cancer screening and problem solving.

Shermis et al., 2017 Qualitative study

Zhang et al., 202014 Retrospective study
To investigate the adjuvant efficacy of US and BSGI for dense breasts.
There is currently no consensus among specialists or imaging societies as to the need to use BPI or additional screening. Therefore, patients should be guided on the balance between benefits and harms.

Molecular breast imaging linked to a high incremental cancer detection rate of $7.7 \%$ at an acceptable radiation dose.

The integration of MBI into clinical practice was proven simple, easy to implement, with high patient satisfaction and easy reimbursement.

For women with dense breasts, mammography plus BSGI or US may improve diagnostic accuracy.

Furthermore, BSGI has high specificity and can reduce invasive biopsies. 
Table 2. Continuation.

\begin{tabular}{|c|c|c|c|}
\hline $\begin{array}{l}\text { Author, year of } \\
\text { publication, study design }\end{array}$ & Objectives & $\begin{array}{l}\text { Interventions/ } \\
\text { methods }\end{array}$ & Results/Conclusions \\
\hline $\begin{array}{l}\text { Yu et al., } 2016^{15} \\
\text { Retrospective study }\end{array}$ & $\begin{array}{l}\text { To analyze the diagnostic value of } \\
\text { BSGI for Chinese women. }\end{array}$ & NA & $\begin{array}{l}\text { BSGI may help improve the ability to } \\
\text { diagnose early-stage breast cancer } \\
\text { among Chinese women, particularly } \\
\text { for ductal carcinoma in situ (DCIS), } \\
\text { mammographically dense breasts, and } \\
\text { non-luminal breast cancer A. }\end{array}$ \\
\hline $\begin{array}{l}\text { Rhodes et al., } 2011^{16} \\
\text { Prospective study }\end{array}$ & $\begin{array}{l}\text { To compare the performance of } \\
\text { dedicated gamma camera and } \\
\text { mammography in screening women } \\
\text { with dense breasts. }\end{array}$ & NA & $\begin{array}{c}\text { The addition of gamma-camera imaging to } \\
\text { mammography increased significantly the } \\
\text { detection of node-negative breast cancer } \\
\text { in dense breasts. }\end{array}$ \\
\hline $\begin{array}{l}\text { Hendrick et al., } 2016^{17} \\
\text { Retrospective study }\end{array}$ & $\begin{array}{c}\text { To estimate radiation-induced } \\
\text { cancer mortality for mammography } \\
\text { and MBI based on the biological } \\
\text { effects of reporting ionizing } \\
\text { radiation VII in asymptomatic } \\
\text { women with dense breasts aged } 40 \\
\text { to } 79 \text { years. }\end{array}$ & NA & $\begin{array}{l}\text { The radiation benefit-risk ratio is } \\
\text { estimated at } 13 \text { for } 40 \text { to } 49 \text { years with } \\
\text { mammography, and the value doubles } \\
\text { for each subsequent age range, from } 10 \\
\text { years to } 70-79 \text { years. For BSGl, this ratio } \\
\text { is estimated at } 5 \text { for women aged } 40-49 \\
\text { years and doubles at } 70-79 \text { years. }\end{array}$ \\
\hline $\begin{array}{l}\text { Hruska et al., } 2015^{18} \\
\text { Prospective study }\end{array}$ & $\begin{array}{l}\text { To investigate the diagnostic gain } \\
\text { and costs generated by adding } \\
\text { MBI to screening mammography in } \\
\text { women with dense breasts. }\end{array}$ & $\begin{array}{l}\text { Adding MBI to } \\
\text { mammography for } \\
\text { screening of dense } \\
\text { breasts }\end{array}$ & $\begin{array}{c}\text { There was an increase in the overall costs } \\
\text { and rate of benign biopsies, but also an } \\
\text { increase in the rate of cancer detection, } \\
\text { which resulted in a lower cost per } \\
\text { case detected. }\end{array}$ \\
\hline $\begin{array}{l}\text { Hruska et al., } 2016^{19} \\
\text { Case-control study }\end{array}$ & $\begin{array}{l}\text { To investigate whether } \mathrm{BPU} \text { in } \mathrm{MBI} \text { is } \\
\text { a risk factor for breast cancer. }\end{array}$ & $\begin{array}{l}\text { Associations } \\
\text { between categories } \\
\text { of BPU and risk } \\
\text { of developing } \\
\text { breast cancer }\end{array}$ & $\begin{array}{l}\text { This study provided the first evidence of } \\
\text { BPU as a risk factor for breast cancer. }\end{array}$ \\
\hline $\begin{array}{l}\text { Hruska et al., } 2019^{20} \\
\text { Prospective study }\end{array}$ & $\begin{array}{l}\text { To explore the feasibility of } \\
\text { offering a short-term low-dose oral } \\
\text { tamoxifen intervention for women } \\
\text { with high BPU and examine whether } \\
\text { this intervention would reduce BPU. }\end{array}$ & $\begin{array}{l}\text { Women with high } \\
\text { BPU had an } \mathrm{MBI} \\
\text { exam, followed } \\
\text { by another after } \\
30 \text { days of oral } \\
\text { tamoxifen. }\end{array}$ & $\begin{array}{l}\text { Short-term intervention with low-dose } \\
\text { tamoxifen may reduce high BPU in MBI for } \\
\text { some patients. Preliminary findings have } \\
\text { suggested that } 10 \mathrm{mg} \text { of tamoxifen per } \\
\text { day may be more effective than } 5 \mathrm{mg} \text { to } \\
\text { induce BPU decline in } 30 \text { days. }\end{array}$ \\
\hline $\begin{array}{l}\text { Yoon et al., } 2015^{21} \\
\text { Retrospective study }\end{array}$ & $\begin{array}{l}\text { To investigate factors that may } \\
\text { affect } \mathrm{MBI} \text { uptake in normal breasts } \\
\text { and the impact of uptake on } \mathrm{MBI} \\
\text { diagnostic performance. }\end{array}$ & NA & $\begin{array}{c}\text { BPE in RNM was the most important } \\
\text { uptake factor in the MBI. High background } \\
\text { uptake or marked background parenchyma } \\
\text { enhancement can diminish MBI } \\
\text { diagnostic performance. }\end{array}$ \\
\hline $\begin{array}{l}\text { Ching et al., } 2018^{22} \\
\text { Retrospective study }\end{array}$ & $\begin{array}{l}\text { To evaluate the correlation between } \\
\text { the characteristics described } \\
\text { in the MBI and the positive } \\
\text { predictive value in the detection of } \\
\text { breast cancer. }\end{array}$ & NA & $\begin{array}{c}\text { Neither mass or non-mass variation nor } \\
\text { the assessment of background uptake } \\
\text { in MBI were significant determinants of } \\
\text { probability of malignancy. Dense breasts } \\
\text { were associated with low predictability } \\
\text { and heterogeneous background uptake } \\
\text { in MBI. }\end{array}$ \\
\hline $\begin{array}{l}\text { Hruska et al., } 2015^{23} \\
\text { Retrospective study }\end{array}$ & $\begin{array}{l}\text { To describe the prevalence of } \\
\text { the BPU categories observed in } \\
\text { MBI screening and to examine its } \\
\text { association with mammographic } \\
\text { density and other clinical factors. }\end{array}$ & NA & $\begin{array}{l}\text { Among women with similar } \\
\text { mammographic density, BPU ranged } \\
\text { from photopenic to marked. The highest } \\
\text { BPU occurred in young, non-menopausal } \\
\text { patients on hormone therapy. }\end{array}$ \\
\hline $\begin{array}{l}\text { Hruska et al., } 2015^{24} \\
\text { Cohort study }\end{array}$ & $\begin{array}{c}\text { To assess the impact of the } \\
\text { menstrual cycle phase on the aspect } \\
\text { of BPU. }\end{array}$ & $\begin{array}{l}\text { MBI study in } \\
\text { different phases of } \\
\text { the menstrual cycle. }\end{array}$ & $\begin{array}{l}\text { When high BPU was present, it was } \\
\text { more often seen during the luteal phase } \\
\text { compared to the follicular phase, and in } \\
\text { women with dense breasts compared to } \\
\text { non-dense breasts. }\end{array}$ \\
\hline $\begin{array}{l}\text { Dibble } 2021^{25} \\
\text { Qualitative study }\end{array}$ & $\begin{array}{l}\text { Editorial comment regarding } \\
\text { ARTICLE } 20 \text { [3] }\end{array}$ & NA & $\begin{array}{l}\text { The results of the article in question add } \\
\text { to the growing literature that supports } \\
\text { personalized breast cancer screening } \\
\text { and risk assessment incorporating } \\
\text { imaging biomarkers. }\end{array}$ \\
\hline
\end{tabular}

NA: not applicable; MBI: molecular breast imaging; BPU: background uptake of fibroglandular tissue; BPE: background enhancement of fibroglandular tissue; US: ultrasound. 
Among the advantages of MBI studies, we can highlight a high incremental rate of cancer detection at an acceptable radiation dose, easy integration to implement in clinical practice, with high patient satisfaction, low cost, good tolerance and high reproducibility ${ }^{10-13}$.

Two studies ${ }^{14,15}$ compared other imaging methods with MBI to assess dense breasts. These studies selected Chinese women with dense breasts upon mammography and submitted them to other investigation methods, such as ultrasonography (US), magnetic resonance imaging (MRI) and MBI. In both studies, the sensitivity and specificity of each method were investigated. Yu et al. ${ }^{15}$ concluded that the isolated sensitivity and specificity of MBI were, respectively, $80.35 \%$ and $83.19 \%$ for the detection of breast cancer. The MBI, however, has low sensitivity to detect axillary lymph nodes (32\%). Zhang et al. ${ }^{14}$ evaluated the sensitivity, specificity and diagnostic accuracy of the combination of mammography and MBI versus mammography and US. The increased diagnostic specificity of MBI was $30.8 \%$ versus $20.6 \%$ of US (10.3\% difference, $p=0.003$ ). There was no difference between MBI or US in increasing the sensitivity of diagnosis in mammography (increased sensitivity $25.2 \%$ versus $22.1 \%$, difference $3.2 \%, p=0.23$ ).

The study by Rhodes et al. ${ }^{6}$ showed the performance characteristics of MBI and mammography for screening cancer in

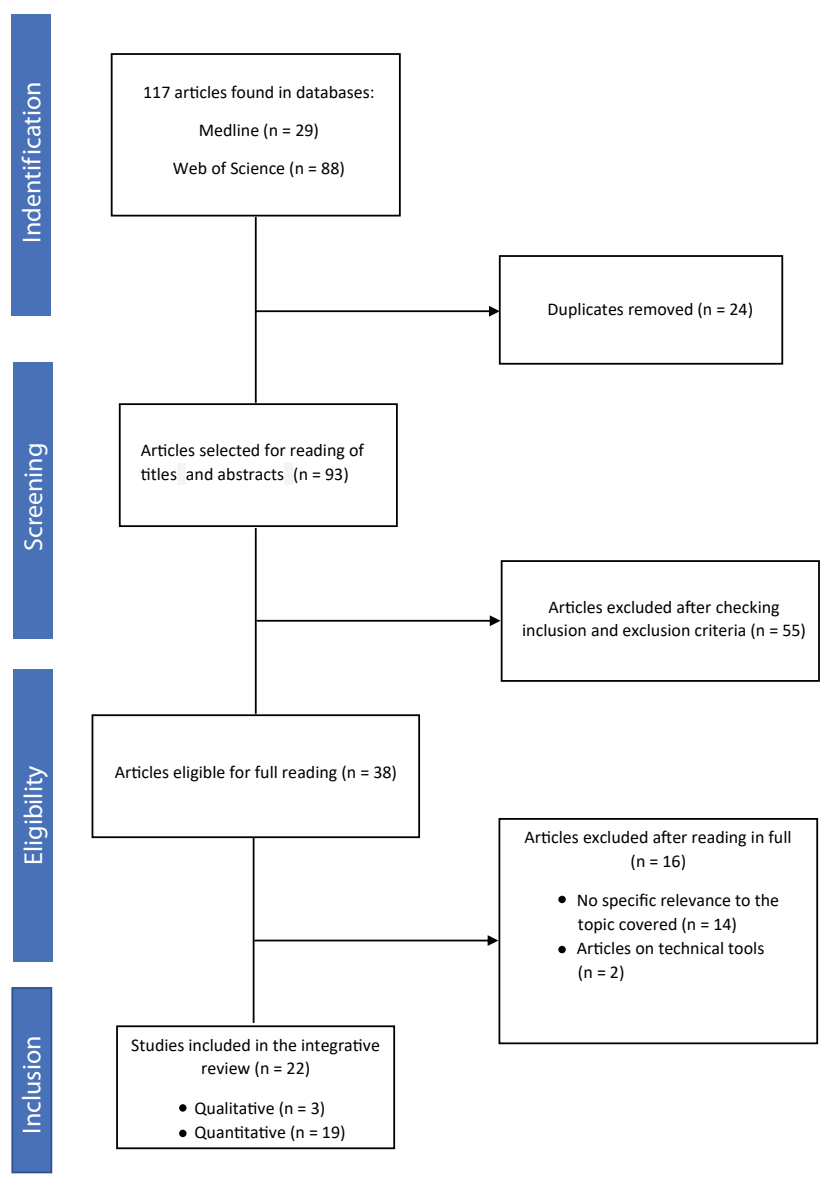

Figure 1. Article search and selection process. women with dense breasts. Combined mammography and MBI were significantly more sensitive than mammography alone ( $91 \%$ versus $27 \%, p=0.016)$. MBI and mammography specificities were similar ( $93 \%$ and $91 \%$, respectively). The positive predictive value (PPV) of a screening test with abnormal results was significantly higher for MBI compared to mammography ( $12 \%$ versus $3 \%, p=$ $0.01)$. Although recall rates for mammography and MBI did not differ significantly, there was a trend towards a lower recall rate for $\mathrm{MBI}^{16}$. However, Hendrick and Tredennick reported that, while the lowest dose of MBI has benefit-risk estimates greater than 1 for women with dense breasts and age 40 years or older, this estimate is not outweighed by the benefit-risk related to screening mammography ${ }^{17}$.

Several techniques can be used to further screen women with dense breasts. Low radiation dose MBI can be one of these ${ }^{18}$. BPU of fibroglandular tissue, which refers to the level of Sestamibi- ${ }^{99 \mathrm{~m}} \mathrm{Tc}$ uptake within fibroglandular tissue on molecular breast imaging (MBI), has been identified as a strong risk factor for breast cancer, regardless of mammographic density 2,19,20. $^{2}$.

Yoon et al. investigated factors that could affect MBI background uptake in normal breasts and the impact of MBI background uptake on the diagnostic performance of MBI. Background parenchyma enhancement (BPE) on MRI was the most important factor. A high background uptake or marked BPE can decrease the diagnostic performance of $\mathrm{MBI}^{21}$.

Some studies used subjective categories to classify BPU into four groups: photopenic aspect (lower uptake than that observed in subcutaneous fat), minimal to mild (equal to or a little higher than fat), moderate (greater than mild, but less than twice the uptake in fat) and accentuated (at least twice greater than seen in fat $)^{2,3,19,22}$. Due to possible variations between different observers, a quantitative method was proposed for a more accurate reproducibility of this classification ${ }^{2}$.

A retrospective study carried out in 2015 with more than 1,100 women reported some clinical factors as associated with higher levels of BPU. Young, non-menopausal patients on hormone replacement therapy (HRT) were rated in the moderate to severe category ${ }^{23}$. Another study showed effects of menstrual cycle phase on BPU. When high BPU values were seen, they were more frequent in the luteal phase and in women with dense breasts $^{24}$. Hruska et al. stated that short-term intervention with low-dose tamoxifen can reduce BPU in MBI for some patients. Preliminary findings suggested that tamoxifen at $10 \mathrm{mg}$ per day was more effective than $5 \mathrm{mg}$ to induce BPU decay in 30 days $^{20}$.

A study from 2018 with 153 women associated the MBI PPV in relation to the character of the lesions, BPU and breast density. Mass or non-mass variability in the character of lesions was not a good determinant of malignancy likelihood. Furthermore, it was concluded that BPU heterogeneity did not significantly affect the prediction of positivity. However, dense breasts had more findings than non-dense breasts ${ }^{22}$. 
The association of BPU with predicting the development of breast cancer in post- and pre-menopausal women in five years was evaluated in a 2020 cohort. Increased BPU was shown to be associated with an increased risk of breast cancer in post-menopausal women. However, a non-significant association was seen in premenopausal women. In postmenopausal women, BPU provides discriminatory accuracy to predict breast cancer risk when combined with the Gail or BCSC models (which include risk factors in the assessment). The group of postmenopausal women, with low BPU and on hormone replacement therapy was reported as having the lowest risk for breast cancer ${ }^{3,25}$.

\section{DISCUSSION}

MBI in clinical practice, as a complement to mammography in the detection of breast cancer, has been reported by several studies $^{6,7,22}$. The pros of this imaging method are: easy interpretation, high rate of inter-observer agreement, high diagnostic accuracy and not being operator-dependent, like ultrasonography. However, the method does have some disadvantages, including the use of radiation and low sensitivity in detecting axillary lymph nodes ${ }^{15}$.

When compared to MRI, MBI has similar sensitivity and specificity for breast cancer, except in women who are at high risk of developing the disease, in which the sensitivity of MBI is slightly higher than that of $\mathrm{MRI}^{7}$. However, further studies are needed to better characterize this difference.

The cost of MBI is comparable to the cost of 3D mammography and approximately one-tenth of the cost of $\mathrm{MRI}^{11}$. The addition of MBI to screening mammography in women with dense breasts was already proven to increase the overall cost and rate of benign biopsies. However, there is an increase in cancer detection when compared to mammography alone, which represents a great advantage, as it results in a lower cost per case detected ${ }^{18}$.

Although concerns about exposure to MBI radiation have limited its acceptance in the past, low doses have enabled the use of this method for routine screening ${ }^{3}$. This allowed an effective supplemental imaging technique for subgroups of women in which the sensitivity of mammography is limited. However, further studies are needed to assess whether MBI could replace mammography in certain populations or whether the two modalities could be used together ${ }^{16}$.

MBI images are known to have high sensitivity in detecting breast cancer, both in patients with dense breast tissue and in patients with non-dense breast tissue. Choi et al. showed that the accuracy of predicting malignancy in breast lesions could be improved by analyzing uptake characteristics rather than diagnosing malignancy based solely on the presence of radiotracer uptake. The results also associate higher uptake intensity with a higher frequency of malignancy ${ }^{8}$.

With regard to patients with dense breasts, studies suggest that MBI is a very useful imaging modality for the detection of tumors ${ }^{12,13}$.
The increase in MBI as an adjuvant method can promote early detection of breast cancer, offer more treatment options and reduce morbidity and mortality among these patients $\mathrm{s}^{14,15}$. Furthermore, considering the supplementary assessment of dense breasts through MBI, the recall rate to reassess the exam varies from $7 \%$ to $13 \%$, which is lower than that reported for breast ultrasound and $\mathrm{MRI}^{11}$.

BPU assessed in the MBI of women with dense breast tissue can function as an additional risk factor that can help identify the subgroup of patients that would most benefit from screening or primary prevention options ${ }^{19}$. BPU was shown to be strongly associated with the risk of developing breast cancer, regardless of mammographic density and hormonal factors ${ }^{2}$.

However, a study by Hruska et al. showed higher BPU values during the luteal phase in non-menopausal women, compared to the follicular phase of the menstrual cycle, and in women with dense breasts compared to women with non-dense breasts ${ }^{24}$. Another study showed that postmenopausal women with dense breasts and high BPU were identified as being at particularly high absolute risk, while the lowest risk subgroup were postmenopausal women on hormone therapy with low BPU. This finding suggests that low BPU may identify a subset of women with hormone-unresponsive breast tissue and therefore no increased risk of breast cancer due to hormone therapy ${ }^{3}$.

Short-term administration of low-dose tamoxifen has shown a reduction in BPU in some women, which could suggest that this medication reduces the risk of breast cancer. However, given the variability of BPU response to tamoxifen among the study participants, a future study is needed ${ }^{20}$.

\section{CONCLUSIONS}

We can conclude, after a careful review of the studies selected, that the use of MBI as a complementary screening method for dense breasts would be of great value in clinical practice, as it can increase the diagnostic sensitivity and specificity at low cost and good tolerance by patients.

The use of BPU along with MBI should be considered in these patients, since the level of fibroglandular tissue uptake was associated with risk of developing breast cancer, regardless of mammographic density and hormonal factors, which allows for the identification of a subset of women with dense breasts upon mammography and at high risk of developing neoplasia.

\section{AUTHORS' CONTRIBUTION}

C.L.S.V.: Conceptualization, data curation, formal analysis, funding acquisition, investigation, methodology, project administration, resources, software, supervision, validation, visualization, writing - original draft, writing - review \& editing.

LPCVG: Conceptualization, data curation, formal analysis, funding acquisition, investigation, methodology, project administration, 
resources, software, validation, visualization, writing - original draft, writing - review \& editing.

DNP: Data curation, formal analysis, funding acquisition, investigation, project administration, resources, software, supervision, validation, visualization, writing - original draft, writing - review \& editing.
ASM: Data curation, formal analysis, funding acquisition, investigation, resources, software, visualization, writing original draft.

RFBA: Conceptualization, formal analysis, methodology, project administration, resources, supervision, validation, visualization, writing - review \& editing.

\section{REFERENCES}

1. World Health Organization. International Agency for Research on Cancer. Globocan 2018 [Internet]. World Health Organization [cited on Set 14, 2020]. Available from: https:// gco.iarc.fr

2. Hruska CB, Geske JR, Swanson TN, Mammel AN, Lake DS, Manduca A, et al. Quantitative background parenchymal uptake on molecular breast imaging and breast cancer risk: a case-control study. Breast Cancer Res. 2018;20(1):46. https:// doi.org/10.1186/s13058-018-0973-3

3. Hruska CB, Geske JR, Conners AL, Whaley DH, Rhodes DJ, O'Connor MK, et al. Background Parenchymal Uptake on Molecular Breast Imaging and Breast Cancer Risk: A Cohort Study. Am J Roentgenol. 2021;216(5):1193-204. https://doi. org/10.2214/AJR.20.23854

4. Critical Appraisal Skills Programme (CASP). [Internet]. Oxford Centre for Triple Value Healthcare; 2019 [cited on Oct 26, 2020]. Available from https://casp-uk.net/casp-tools-checklists

5. Checklist for Systematic Reviews and Research Syntheses. Critical Appraisal tools for use in JBI Systematic Reviews [Internet]. 2020 [cited on Oct 26, 2020]. Available from: https:// joannabriggs.org/critical-appraisal-tools

6. Rhodes DJ, Hruska CB, Conners AL, Tortorelli CL, Maxwell RW, Jones KN, et al. Molecular breast imaging at reduced radiation dose for supplemental screening in mammographically dense breasts. Am J Roentgenol. 2015;204(2):241-51. https://dx.doi. org/10.2214\%2FAJR.14.13357

7. Brem RF, Ruda RC, Yang JL, Coffey CM, Rapelyea JA. Breastspecific $\gamma$-imaging for the detection of mammographically occult breast cancer in women at increased risk. J Nucl Med. 2016;57(5):678-84. https://doi.org/10.2967/jnumed.115.168385

8. Choi EK, Im JJ, Park CS, Chung YA, Kim K, Oh JK. Usefulness of feature analysis of breast-specific gamma imaging for predicting malignancy. Eur Radiol. 2018;28(12):5195-202. https://doi.org/10.1007/s00330-018-5563-3

9. Rechtman LR, Lenihan MJ, Lieberman JH, Teal CB, Torrente J, Rapelyea JA, et al. Breast-specific gamma imaging for the detection of breast cancer in dense versus nondense breasts. Am J Roentgenol. 2014;202(2):293-8. https://doi.org/10.2214/ ajr.13.11585

10. Conners AL, Hruska CB, Tortorelli CL, Maxwell RW, Rhodes DJ, Boughey JC, et al. Lexicon for standardized interpretation of gamma camera molecular breast imaging: Observer agreement and diagnostic accuracy. Eur J Nucl Med Mol Imaging. 2012;39(6):971-82. https://doi.org/10.1007/s00259011-2054-z
11. Rhodes DJ. Supplemental screening in the dense breast: Does molecular breast imaging have a role? Menopause. 2020;27(1):110-2. https://doi.org/10.1097/ gme.0000000000001471

12. Shermis RB, Wilson KD, Doyle MT, Martin TS, Merryman D, Kudrolli H, et al. Supplemental breast cancer screening with molecular breast imaging for women with dense breast tissue. Am J Roentgenol. 2016;207(2):450-7. https://doi.org/10.2214/ ajr.15.15924

13. Shermis RB, Redfern RE, Burns J, Kudrolli H. Molecular breast imaging in breast cancer screening and problem solving. Radiographics. 2017;37(5):1309-606. https://doi.org/10.1148/ rg.2017160204

14. Zhang Z, Wang W, Wang X, Yu X, Zhu Y, Zhan H, et al. Breastspecific gamma imaging or ultrasonography as adjunct imaging diagnostics in women with mammographically dense breasts. Eur Radiol. 2020;30(11):6062-71. https://doi. org/10.1007/s00330-020-06950-2

15. Yu X, Hu G, Zhang Z, Qiu F, Shao X, Wang X, et al. Retrospective and comparative analysis of $99 \mathrm{mTc}$-Sestamibi breast specific gamma imaging versus mammography, ultrasound, and magnetic resonance imaging for the detection of breast cancer in Chinese women. BMC Cancer. 2016;16(1):1-10. https://doi. org/10.1186/s12885-016-2537-1

16. Rhodes DJ, Hruska CB, Phillips SW, Whaley DH, O’Connor MK. Dedicated dual-head gamma imaging for breast cancer screening in women with mammographically dense breasts. Radiology. 2011;258(1):106-18. https://doi.org/10.1148/ radiol. 10100625

17. Hendrick RE, Tredennick T. Benefit to radiation risk of breastspecific gamma imaging compared with mammography in screening asymptomatic women with dense breasts. Radiology. 2016;281(2):583-8. https://doi.org/10.1148/ radiol.2016151581

18. Hruska CB, Conners AL, Jones KN, O'Connor MK, Moriarty JP, Boughey JC, et al. Diagnostic workup and costs of a single supplemental molecular breast imaging screen of mammographically dense breasts. Am J Roentgenol. 2015;204(6):1345-53. https://doi.org/10.2214/ ajr.14.13306

19. Hruska CB, Scott CG, Conners AL, Whaley DH, Rhodes DJ, Carter RE, et al. Background parenchymal uptake on molecular breast imaging as a breast cancer risk factor: A case-control study. Breast Cancer Res. 2016;18(1):42. https:// doi.org/10.1186/s13058-016-0704-6 
20. Hruska CB, Hunt KN, Conners AL, Geske JR, Brandt KR, Degnim AC, et al. Impact of short-term low-dose tamoxifen on molecular breast imaging background parenchymal uptake: A pilot study. Breast Cancer Res. 2019;21(1):38. https://doi. org/10.1186/s13058-019-1120-5

21. Yoon HJ, Kim Y, Lee JE, Kim BS. Background 99mTcmethoxyisobutylisonitrile uptake of breast-specific gamma imaging in relation to background parenchymal enhancement in magnetic resonance imaging. Eur Radiol. 2015;25(1):32-40. https://doi.org/10.1007/s00330-014-3400-x

22. Ching JG, Brem RF. Breast Lesions Detected via Molecular Breast Imaging: Physiological Parameters Affecting Interpretation. Acad Radiol. 2018;25(12):1568-76. https://doi. org/10.1016/j.acra.2018.03.004
23. Hruska CB, Rhodes DJ, Conners AL, Jones KN, Carter RE, Lingineni RK, et al. Background parenchymal uptake during molecular breast imaging and associated clinical factors. Am J Roentgenol. 2015;204(3):W363-70. https://doi.org/10.2214/ ajr.14.12979

24. Hruska CB, Conners AL, Vachon CM, O'Connor MK, Shuster LT, Bartley AC, et al. Effect of Menstrual Cycle Phase on Background Parenchymal Uptake at Molecular Breast Imaging. Acad Radiol. 2015;22(9):1147-56. https://dx.doi. org/10.1016\%2Fj.acra.2015.04.003

25. Dibble EH. Editorial Comment on "Background Parenchymal Uptake on Molecular Breast Imaging and Breast Cancer Risk: A Cohort Study." Am J Roentgenol. 2021;216(5):1204. https:// doi.org/10.2214/AJR.20.24456 